\title{
Physiological Performance of Common Bean Seeds Treated with Bioactivator with and without Moisture Restriction
}

\author{
Andréia da Silva Almeida ${ }^{*}$, Francisco Amaral Villela1, Geri Eduardo Meneghello", \\ Cristiane Deuner ${ }^{1}$, Lilian Madruga de Tunes ${ }^{1}$, Paulo Dejalma Zimmer ${ }^{1}$, Adilson Jauer ${ }^{2}$ \\ ${ }^{1}$ PPG em Ciência e Tecnologia de Sementes, Universidade Federal de Pelotas, Pelotas, Brasil \\ ${ }^{2}$ Syngenta Crop Protection, Pelotas, Brasil \\ Email: ${ }^{*}$ andreiasalmeida@yahoo.com.br
}

Received 30 October 2014; revised 29 November 2014; accepted 6 December 2014

Copyright (C) 2014 by authors and Scientific Research Publishing Inc.

This work is licensed under the Creative Commons Attribution International License (CC BY). http://creativecommons.org/licenses/by/4.0/

(c) (i) Open Access

\begin{abstract}
The commonbean (Phaseolus vulgaris L.) is an important agricultural crop due to its nutritional properties. Insecticides and fungicides employed to control pests and diseases in the common bean may cause as yet unknown effects on the plant's morphology and metabolism. Bioactivators are complex organic substances, capable of exerting modification upon growth patterns, plant DNA transcription, gene expression, metabolic enzymes and mineral nutrition. Thiamethoxam insecticide has shown positive action on the enhancement of vigor expression, phytomass accretion and the promotion of deeper root systems. The aim of this work was to evaluate the effect of thiamethoxam on the physiological performance of common bean seeds. Seeds from cultivars Pérola and IAPAR Siriri were treated to thiamethoxam concentrations of $0,100,200,300,400$ and 500 $\mathrm{mL} \cdot \mathrm{kg}^{-1}$ seed. Physiological quality was measured through tests for germination value, first count, cold test, accelerated aging and seedling shoot and root lengths, all undertaken in the presence and absence of moisture stress. Thiamethoxam stimulated the physiological performance of common bean seeds under moisture stress or in the absence of it, with levels varying according to cultivar and seed lot. The best physiological seed performance was obtained within the range of $200 \mathrm{~mL} \cdot 100 \mathrm{~kg}^{-1}$ seed to $400 \mathrm{~mL} \cdot 100 \mathrm{~kg}^{-1}$ seed.
\end{abstract}

\section{Keywords}

Phaseolus vulgaris L., Bioactivator, Seeds, Vigor

\footnotetext{
${ }^{*}$ Corresponding author.
} 


\section{Introduction}

The common bean (Phaseolus vulgaris L.) is a plant belonging to the Fabaceae family, whose cropping is important for human consumption due to its high protein content, as well as that of carbohydrates and minerals. Common bean cultivation is widespread throughout Brazilian territory and in many Latin American countries, where it is widely consumed with rice, which is rich in starch, thus providing a balanced diet for vast sectors of the population [1].

Management decisions for successful cropping involve, among other things, the relative uncertainty of predicting weather extremes, which has been a major concern for agribusiness entrepreneurs. These entrepreneurs must have sufficient information to pursue management decisions with the necessary antecedence, which in some cases must be predicted months in advance [2]. Crop management involves, in most cases, the use of pesticides, insecticides and fungicides, which are assessed through their efficiency in the control of pests and diseases. Some, however, may have unknown effects on plant metabolism as well as cause alterations in plant morphology [3]. Research results indicate that certain insecticides such as carbofuran [4] and thiamethoxam [5] can cause physiological and morphological changes in plants. Hormone regulators have received increasing attention, particularly in high-value crops, as cropping techniques continue to evolve. Bioactivators are complex organic substances which modify plant growth, and are able to act on plant DNA transcription, gene expression, membrane proteins, metabolic enzymes and mineral nutrition [6]. The insecticide thiamethoxam has shown positive effects through increased seed vigor expression, biomass accretion, increased photosynthetic rate and development of deeper roots [7].

Thiamethoxam is transported within the plant cell system, enhancing physiological reactions such as protein expression, which is responsible for defense mechanisms against plant stress. These stress-reducing mechanisms allow seedlings to deal better with an assortment of adverse conditions such as drought, low soil $\mathrm{pH}$, high soil salinity, the presence of free radicals, high temperatures, toxic effects due to high levels of soil aluminum, and injuries caused by pests, wind, hail, virus attacks and nutrient deficiency. Thiamethoxam has also shown phytotonic effects, providing favorable conditions for faster initial development by enhancing the expression of seedling vigor. Increases in seed germination, vigor, productivity, leaf area, root depth and stand uniformity have been observed in soybeans by [8], resulting in faster establishment and growth rate. In turn, these higher growth rates could yield higher competitive ability for the plant against weeds, and favor the absorption of essential nutrients present in the soil [7].

Plants treated with thiamethoxam show greater tolerance to stress factors and, can consequently develop more vigorously under suboptimal conditions, increasing the likelihood of plants achieving their productivity potential.

Considering the need for further research regarding the effect of thiamethoxam and specifically its potential benefits on the treatment of common bean seeds, the present study aimed to evaluate the influence of thiamethoxam on the physiological performance of seeds from this species when germinated under different levels of moisture restriction.

\section{Material and Methods}

The work was conducted at the Seed Testing Laboratory, Faculty of Agronomy Eliseu Maciel from the Federal University of Pelotas (UFPel), Pelotas, RS, Brazil. Seeds from two common bean cultivars, Pérola and IAPAR Siriri, were treated with a commercial product containing $35 \mathrm{~g} \cdot \mathrm{L}$ of thiamethoxama. Six doses were tested, ranging from zero to $5 \mathrm{~mL}$ of product per $\mathrm{kg}$ of seed, in increments of $1 \mathrm{~mL}$, equivalent to zero up to a maximum of $0.175 \mathrm{~g}$ a.i. per $\mathrm{kg}$ of seed.

The mixture of commercial product and moisture was applied to the seeds in plastic bags used as containers with the aid of a pipette, to ensure the application of the correct dosage according to the specific treatment. The volume of the mixture corresponded to that of $0.6 \mathrm{~L}$ per $100 \mathrm{~kg}$ of seeds. The levels of moisture deficit were zero restriction and $-0.4 \mathrm{MPa}$, comprising a full factorial design with six doses of thiamethoxam combined with two levels of moisture stress.

The moisture stress level was obtained by means of an aqueous solution of polyethylene glycol (PEG 6000), according to the procedure described [9]. The PEG solution was applied on germitest paper substrate, in a volume equivalent to 2.5 times the weight of the dry substrate for all germination tests conducted throughout the experiment. 
Treatment effects were quantified through the following tests.

Germination: four replicates with four subsamples of 50 seeds per treatment were used. The seeds were placed on germitest paper rolls, moistened with distilled moisture at a ratio of 2.5 times the weight of the dry paper and kept in an incubator at a set temperature of $25^{\circ} \mathrm{C}$. The germination value readings were performed according to the Rules for Seed Testing [10], consisting of two counts conducted at five and eight days, respectively. The results were expressed as percentage of normal seedlings.

First germination count: performed on the fifth day after the paper rolls were placed in the germination chamber, it recorded the observed percentage of normal seedlings.

Cold germination: four replicates with four subsamples of 50 seeds per treatment were used. The seeds were placed on germitest paper rolls, moistened with distilled moisture at a ratio of 2.5 times the weight of the dry paper and kept in a refrigerator at a set temperature of $10^{\circ} \mathrm{C}$ for seven days. After this, the germitest paper rolls were placed in the germination chamber set at $25^{\circ} \mathrm{C}$. The evaluations were performed according to the Rules for Seed Testing [10]. The count for normal seedlings was performed after five days in the germination chamber and the results expressed as percentage of normal seedlings.

Accelerated aging: this test was performed using plastic boxes, according to [11]. The seeds were distributed in a single layer on the inner screen, and the bottom filled with $40 \mathrm{~mL}$ of distilled moisture. All boxes were incubated at $42^{\circ} \mathrm{C}$ for 72 hours. At the end of the aging period, the seeds were placed on germitest paper and followed the same procedure described for the germination test.

Seedling length: following the same procedure described previously for the germination test, rolls containing fifteen seeds each provided the seedlings necessary for this test. Ten samples of ten seedlings per treatment were collected after five days in the germination chamber. Shoot and root lengths were recorded, the total seedling length resulting from the addition of both, and the results expressed in centimeters per seedling.

A completely randomized $2 \times 6$ factorial design (levels of moisture stress $\times$ levels of thiamethoxam commercial product) with four replicates was established, the data collected as percentage values transformed $(\sqrt{x / 100})$ and treatment effects analyzed through polynomial regression.

\section{Results and Discussion}

Each common bean cultivar was tested through three seed lots. Due to the absence of differences between the two common bean cultivars (Pérola and IAPAR Siriri), data is presented only for cultivar Pérola. The germination values fitted a regression equation (Figure 1), with positive association to dose of thiamethoxam for the three lots, irrespective of the moisture stress level. The quadratic fit increased germination, peaking at the dose of $250 \mathrm{~mL}$ of product per $100 \mathrm{~kg} \cdot \mathrm{seed}^{-1}$, with slight variations between lots, after which germination decreased with increasing doses of the commercial product.

Across the three replicates (seed lots), the range for the increase in the germination values when seeds were not subjected to moisture stress was $16 \%$ to $27 \%$, compared to the check treatment. When the common seed beans were exposed to moisture deficit, the range for the increase was $10 \%$ to $16 \%$ in the germination value. Increases in the germination values due to treatment with thiamethoxam were also observed in soybean seeds [7], carrot seeds [12] and cottonseed [13].

Germination values for the first count fitted a quadratic response curve, regardless of the moisture stress level (Figure 2(a); Figure 2(b)). The positive association between thiamethoxam and germination values peaked at doses close to $260 \mathrm{~mL} \cdot \mathrm{kg}^{-1}$ seed of commercial product. According to [6], soybean seeds treated to thiamethoxam accelerated germination by stimulating enzyme action, which in turn yielded faster emergence rates and higher establishment percentages. Similar results were described for carrot seeds [12] and rice [8].

When the thiamethoxam effect was measured under the cold test, increases in the percentage of normal seedlings were observed for seeds across both moisture level treatments (Figure 3). This behavior was similar for the three lots and for Seed Lot 1, with the least vigor, a $27 \%$ germination value increase was recorded between the check treatment and those with thiamethoxam in the absence of moisture stress. For seeds germinated under moisture stress the difference was of 28 percentage points.

Following a trend similar to that described for the regular germination test, the response curve for the cold test fitted a quadratic model, peaking at doses ranging from $200-300 \mathrm{~mL}$ per $100 \mathrm{~kg}^{-1}$ seed, according to the lot. This response to increasing thiamethoxam dosage is thought to be the result of its movement through the plant cells while simultaneously activating various physiological reactions, such as the expression of functional proteins. 


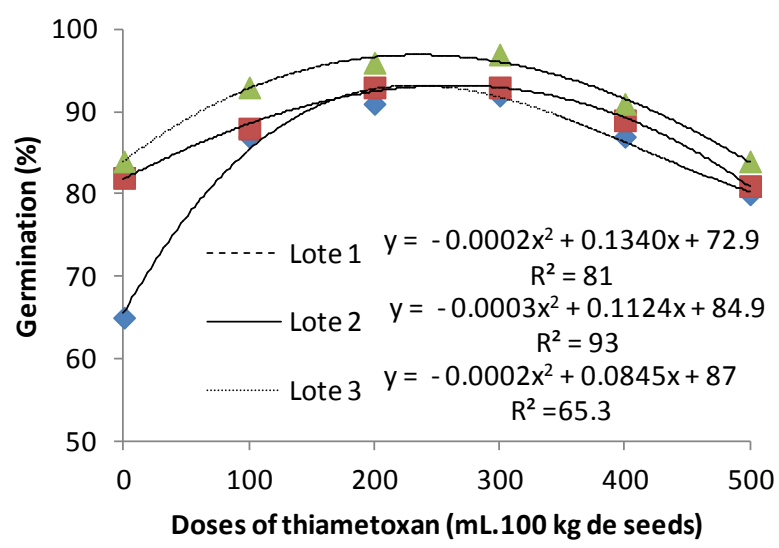

(a)

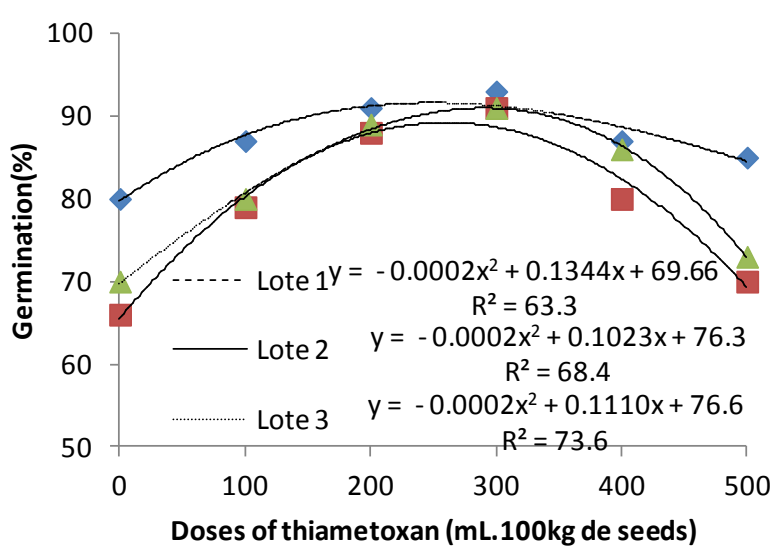

(b)

Figure 1. Germination (\%) of seeds from three lots of common bean, cultivar Pérola, treated to different doses of thiamethoxam, under normal moisture conditions (a) and subjected to moisture stress (b).

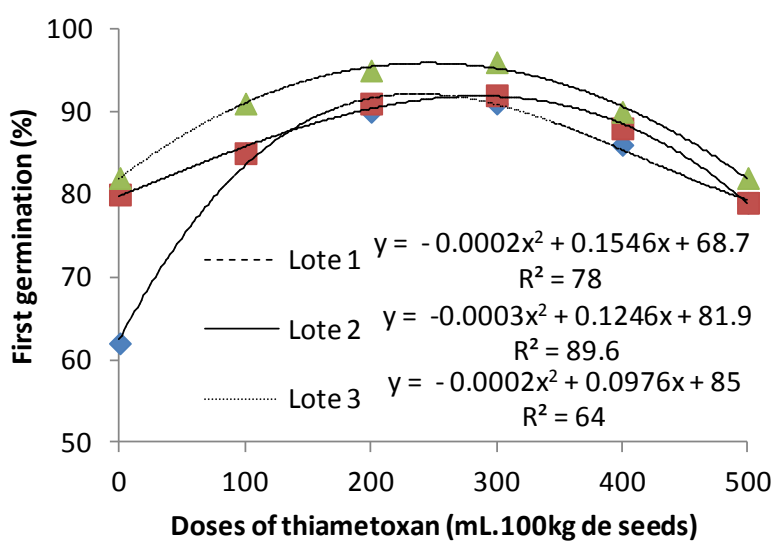

(a)

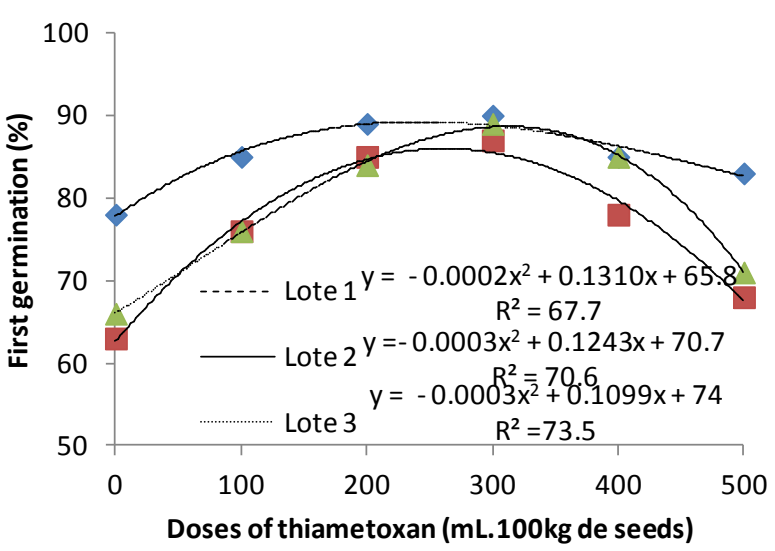

(b)

Figure 2. First germination count (\%) of seeds from three lots of common bean, cultivar Pérola, treated to different doses of thiamethoxam, under normal moisture conditions (a) and subjected to moisture stress (b).

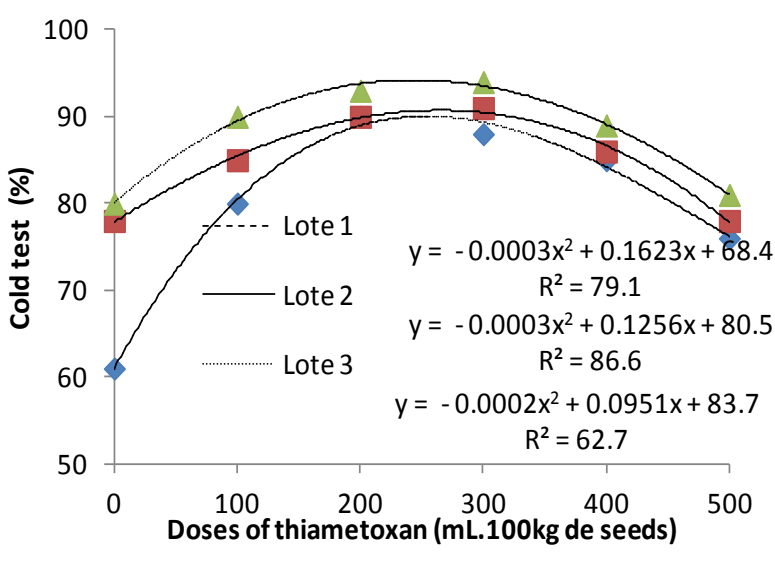

(a)

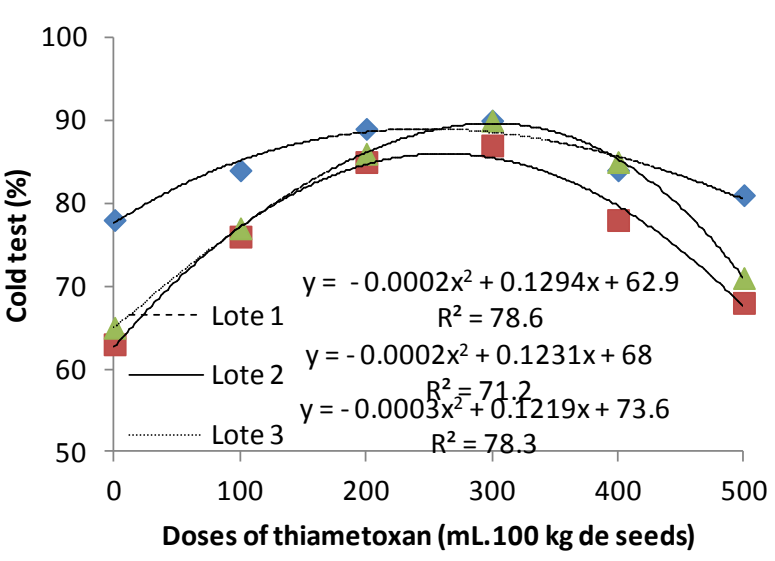

(b)

Figure 3. Cold test germination (\%) of seeds from three lots of common bean, cultivar Pérola, treated to different doses of thiamethoxam, under normal moisture conditions (a) and subjected to moisture stress (b).

These proteins are related to mechanisms of plant defense against stress factors such as drought, high temperatures and toxic effects, improving productivity through the increase in leaf and root area as observed by [14] on 
soybean seeds.

Seeds subjected to accelerated aging showed increases in germination levels to increasing levels of thiamethoxam, regardless of the moisture stress treatments (Figure 4). The quadratic response curve for Seed Lot 3 was somewhat steeper than for the other two seed lots, with greater variations in the germination values. Repeating the trend observed in previous results of this work, the positive response between germination levels and thiamethoxam peaked at 200 - $300 \mathrm{~mL}$ commercial product per $100 \mathrm{~kg}^{-1}$ seed, decreasing thereafter for higher concentrations of the commercial product.

The highest germination values for accelerated-aging treated seeds were obtained with doses equal to 200, 300 and $400 \mathrm{~mL}$ of commercial product per $100 \mathrm{~kg} \cdot \mathrm{seed}^{-1}$, for Seed Lots 1, 2 and 3, respectively, regardless of the moisture stress level applied.

Increases in the germination percentage values were observed for seeds from Lot 1 under both levels of moisture stress, with $27 \%$ increase for seeds on the check moisture stress treatment and of $28 \%$ when germinated under moisture stress conditions.

It was observed that germination of common bean seeds treated to thiamethoxam responded in a quadratic fashion (Figure 5), the best-fit model for all three seed lots. Total seedling length peaked at doses of 200 to 300 $\mathrm{mL}$ of commercial product per $100 \mathrm{~kg} \cdot \mathrm{seed}^{-1}$, according to the lot, after which a decrease occurred for higher doses of the commercial product.

For Seed Lot 3, the dose of $3 \mathrm{~mL}$ commercial product increased seedling length by up to $22 \mathrm{~cm}$ under no moisture stress and up to $18 \mathrm{~cm}$ for seedlings originated from seeds germinated under low moisture level,

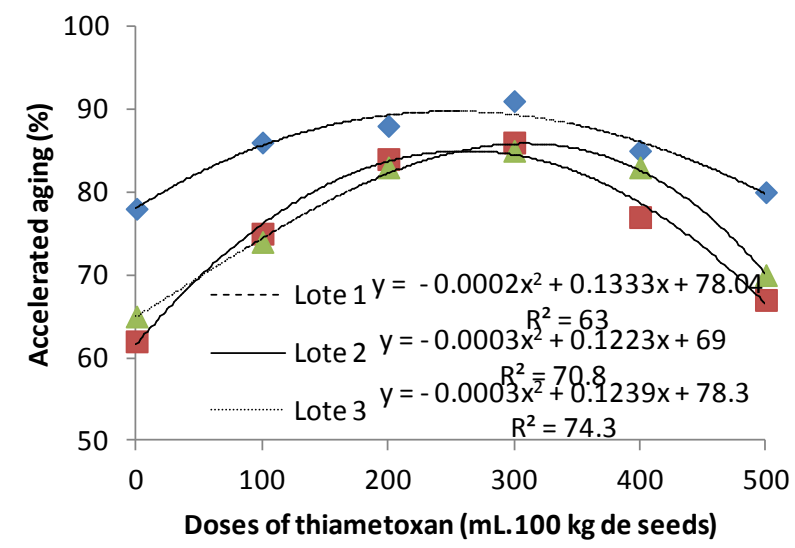

(a)

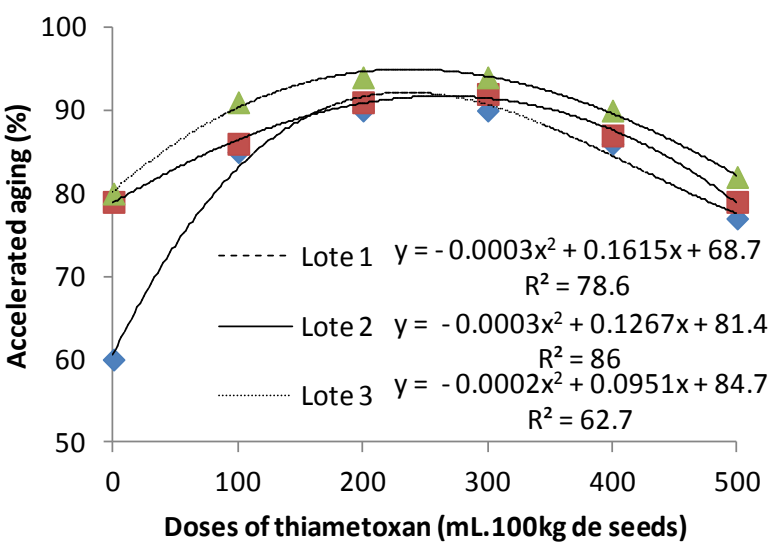

(b)

Figure 4. Accelerated aging germination (\%) of seeds from three lots of common bean, cultivar Pérola, treated to different doses of thiamethoxam, under normal moisture conditions (a) and subjected to moisture stress (b).

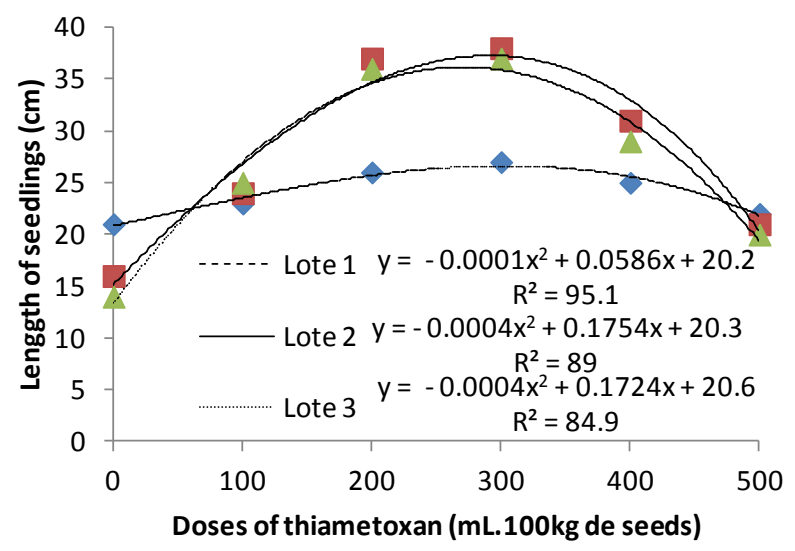

(a)

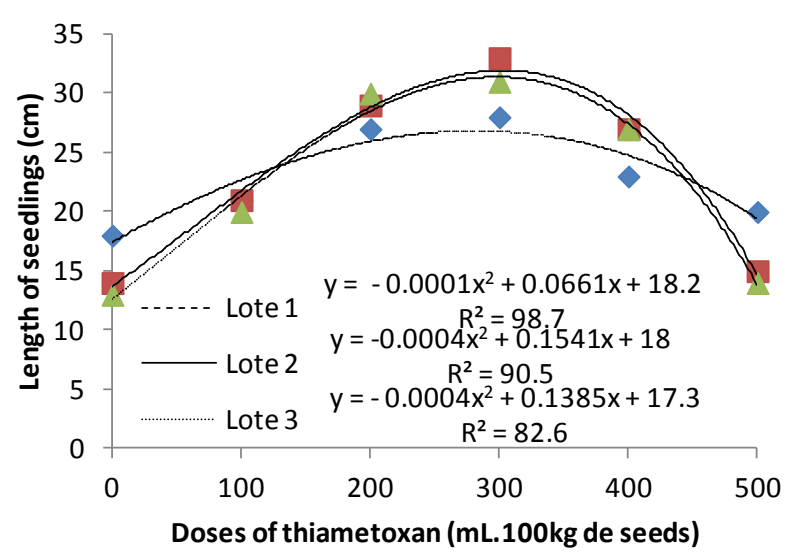

(b)

Figure 5. Total length $(\mathrm{cm})$ of seedlings originating from the seeds of three lots of common bean, cultivar Pérola, treated to different doses of thiamethoxam, under normal moisture conditions (a) and subjected to moisture stress (b). 
compared to the check treatment. The higher seedling length for treatments with thiamethoxam commercial product can be explained by assuming that it enhanced moisture absorption and stomatal resistance, thus improving the plant's moisture balance and making the moisture deficit less severe [3]. Data by [14] in thiamethoxam-treated soybean seeds showed enhanced root development that led to increased nutrient absorption, yielding a larger leaf area with positive effects on the expression of plant vigor.

The favorable effect of thiamethoxam on the increase of root length (Figure 6 and Figure 7) in common bean seedlings has been observed previously by [6] in sugarcane and potatoes, in soybean by [15], in cotton by [13], in carrots by [12], and for rice by [16].

It is noteworthy that the increase in root length due to the thiamethoxam commercial product was higher for Seed Lots 1 and 2, of lower physiological quality than Seed Lot 3.

The shoot length of seedlings with and without moisture stress (Figure 8(a) and Figure 8(b), respectively) increased with increasing doses of the commercial product. In all three seed lots, shoot length showed an increase of at least $5 \mathrm{~cm}$ for untreated seeds in Lot 1 without stress, and of $3 \mathrm{~cm}$ for untreated seeds under moisture stress. The maximum shoot length increase for Seed Lot 2 was $3 \mathrm{~cm}$ and $10 \mathrm{~cm}$, for seeds germinated with and without moisture stress, respectively. The highest responses were obtained for doses of 200 to $300 \mathrm{~mL}$ commercial product per $100 \mathrm{~kg}$ of seed, dependent on the seed lot and level of moisture stress during germination, the highest responses being for seeds under no moisture stress. The increase in shoot length due to different levels of thiamethoxam could eventually enhance stomatal resistance to moisture loss, according to [3], maintaining an active metabolism and increasing resistance to stress. Moreover, according to the same authors, efficiency under

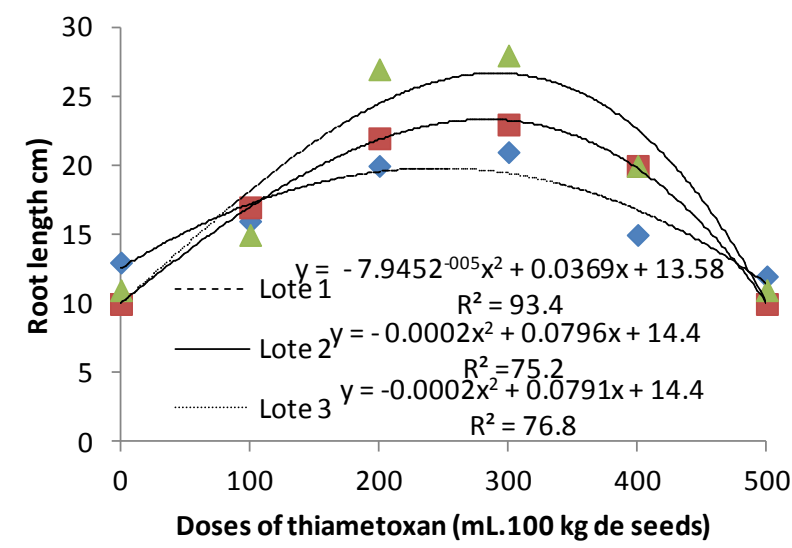

(a)

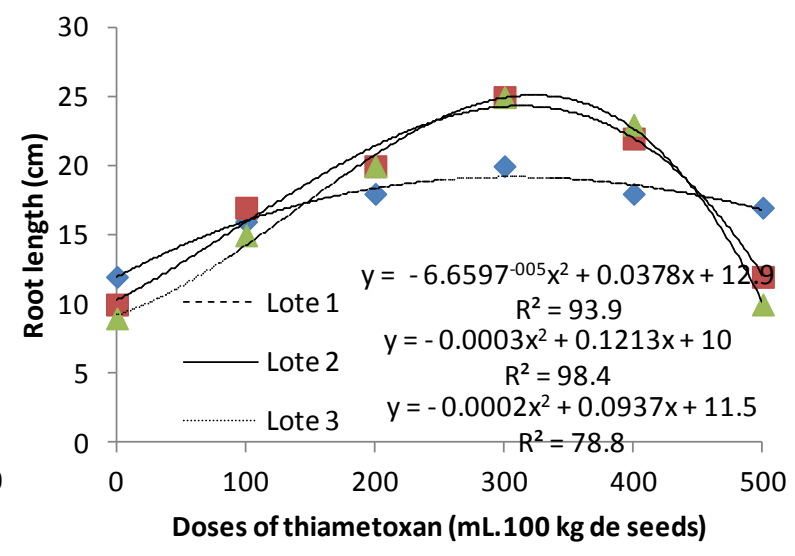

(b)

Figure 6. Root length $(\mathrm{cm})$ of seedlings originated from seeds of three lots of common bean, cultivar Pérola, treated to different doses of thiamethoxam, under normal moisture conditions (a) and subjected to moisture stress (b).

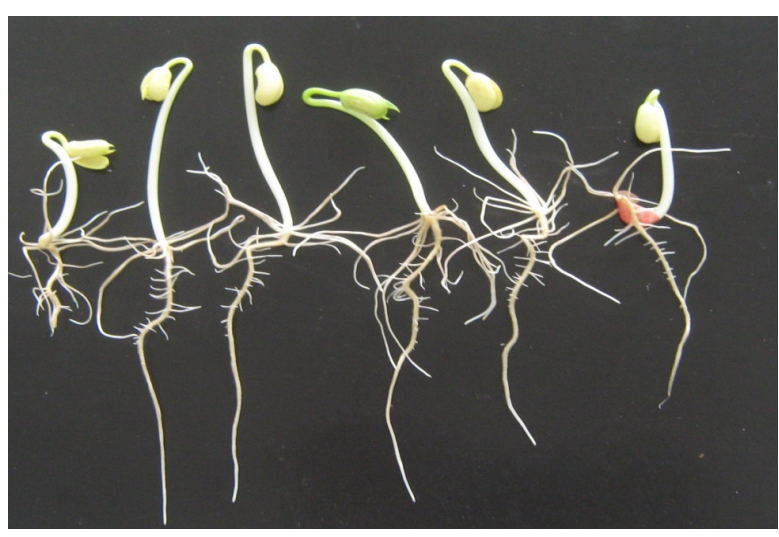

(a)

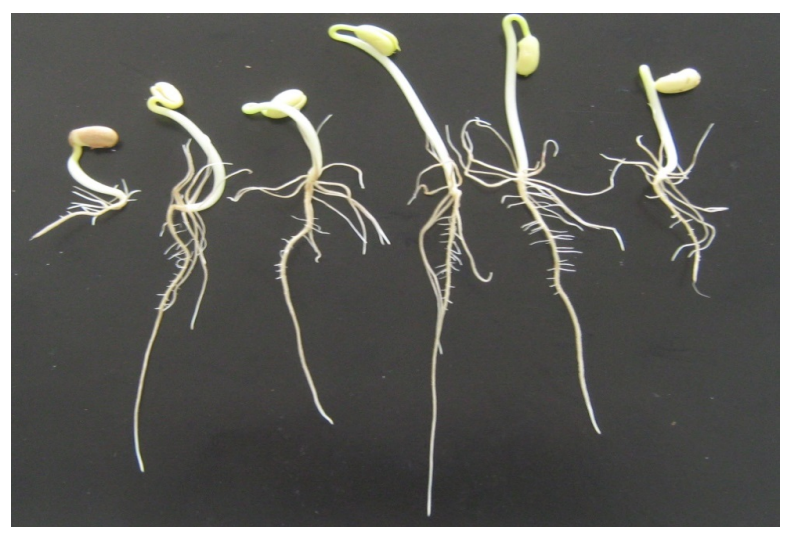

(b)

Figure 7. Root length $(\mathrm{cm})$ of seedlings originated from seeds of three lots of common bean, cultivar Pérola, treated to different doses of thiamethoxam, under normal moisture conditions (a) and subjected to moisture stress (b). 


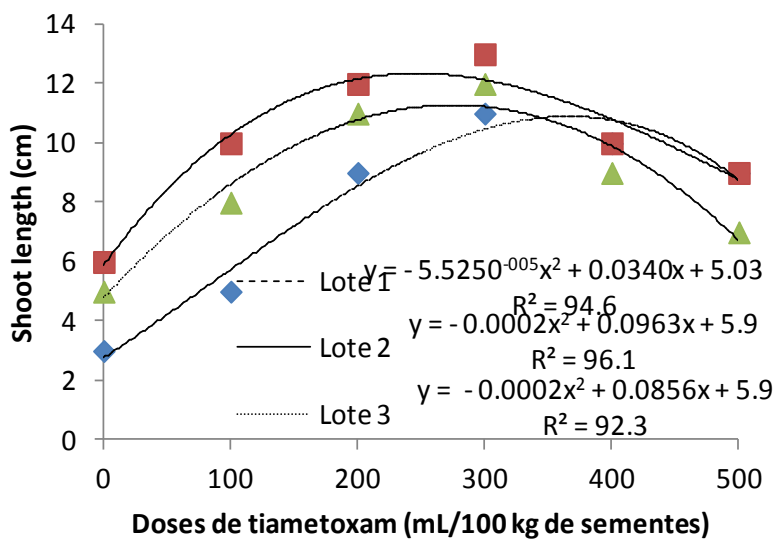

(a)

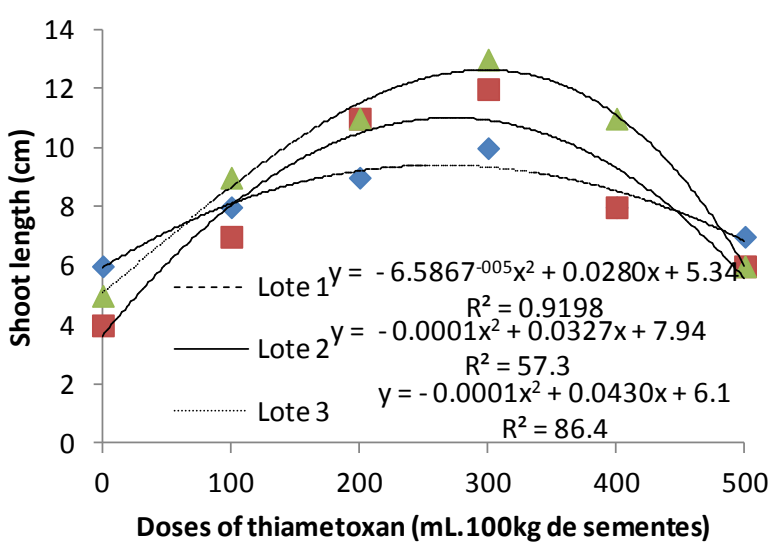

(b)

Figure 8. Shoot length $(\mathrm{cm})$ of seedlings originating from seeds of three lots of common bean, cultivar Pérola, treated to different doses of thiamethoxam, under normal moisture conditions (a) and subjected to moisture stress (b).

field conditions could be improved for crops that show low germination, slow nutrient absorption and transportation, and low assimilation rates.

The different parameters evaluated in seeds subjected or not to moisture stress showed the same trend, with maximum trait values for levels of thiamethoxam commercial product ranging between 200 to $300 \mathrm{~mL} \cdot 100 \mathrm{~kg}^{-1}$ seed. This suggests that under stressful field conditions, the treatment of common bean seeds could ensure the expression of normal seedling development.

In short, thiamethoxam exerted a positive effect on seed germination potential, accelerating the growth of roots and increasing the plant nutrient uptake. When combined with the use of high quality seed, thiamethoxam can enhance a crop's potential yield. The results for the different vigor tests assessed in this work, based on different principles, yielded similar maximum values for the same trend across both moisture level treatments, with differences in the magnitude of the values dependent on the seed lots.

\section{Conclusions}

Thiamethoxam enhances the physiological performance of common bean seeds regardless of the moisture status at germination, to vary magnitudes depending on the seed lot and cultivar.

The recommended dosage ranges from $200 \mathrm{~mL}$ to $400 \mathrm{~mL}$ of commercial product per 100 kilogram of seed, corresponding to $0.07 \mathrm{~g}$ to $0.14 \mathrm{~g}$ a.i. thiamethoxam $\mathrm{kg}^{-1}$ seed of the common bean.

\section{References}

[1] Silva, J.C., Heldwein, A.B, Radons, S.Z., Maldaner, I.C., Trentin, G. and Grimm, E.L. (2011) Necessidade de irrigação para o feijoeiro na região central do Rio Grande do Sul. Revista Brasileira de Agrícola e Ambiental, 15, 1030-1036.

[2] lima, J.S.S., Martins-Filho, S., Lopes, J.C., Garcia, G.O. and Neto, R.S. (2002) Qualidade fisiológica de sementes de feijão produzidas em solo compactado. Revista Brasileira de Sementes, 24, 111-117.

[3] Castro, P.R.C., Pitelli, A.M.C.M., Peres, L.E.P. and Aramaki, P.H. (2007) Análise da atividade reguladora de crescimento vegetal de tiametoxam através de biotestes. Publicatio UEPG (Ponta Grossa), 13, 25-29.

[4] Freitas, D.B., Bezerra, E.C. and Teixeira, N.T. (2001) Aldicarb e Carbofuran e teores de nutrientes na parte aérea de feijoeiro (Phaseolus vulgaris L.) cv. Carioca 80. Ecossistema, 26, 68-70.

[5] Calafiori, M.H. and Barbieri, A.A. (2001) Effects of Seed Treatment with Inseticide on the Germination, Nutrients, Nodulation, Yield and Pest Control in Bean (Phaseolus vulgaris L.) Culture. Ecossistema, Espírito Santo do Pinhal, 26, 97-104.

[6] Castro, P.R.C. and Pereira, M.A. (2008) Bioativadores na agricultura. In: Gazzoni, D.L., Ed., Tiametoxam: Uma revolução na agricultura brasileira, Bogotá, Colômbia, 118-126.

[7] Cataneo, A.C. (2008) Ação do Tiametoxam (Thiametoxam) sobre a germinação de sementes de soja (Glicine Max.L): Enzimas envolvidas na mobilização de reservas e na proteção contra situação de estresse (deficiência hídrica, salinidade e presença de alumínio). In: Gazzoni, D.L., Ed., Tiametoxam: Uma revolução na agricultura brasileira, Bogotá, 
Colômbia, 123-192.

[8] Clavijo, J. (2008) Tiametoxam: Um nuevo concepto em vigor y productividad. Bogotá, Colômbia, 196 p.

[9] Villela, F.A., Doni-Filho, L. and Sequeira, E.L. (1991) Tabela de potencial osmótico em função da concentração de polietileno glicol 6000 e da temperatura. Pesquisa Agropecuária Brasileira, Brasília, 26, 1957-1968.

[10] Brasil (2009) Ministério da Agricultura e da Reforma Agrária. In: Regras para análise de sementes, SNDA/DNDV/ CLAV, Brasília, 398 p.

[11] McDonald, J.R. and Phaneendranath, B.R. (1978) A Modified Accelerated Aging Vigor Test Procedure. Journal of Seed Technology, Lansing, 3, 27-37.

[12] Almeida, A.S., Tillmann, M.A.A., Villela, F.A. and Pinho, M.S. (2009) Bioativador no desempenho fisiológico de sementes de cenoura. Revista Brasileira de Sementes, 31, 87-95. http://dx.doi.org/10.1590/S0101-31222009000300010

[13] Lauxen, L.R., Villela, F.A. and Soares, R.C. (2010) Desempenho fisiológico de sementes de algodão tratadas com tiametoxam. Revista Brasileira de Sementes, Brasília, 32, 61-68.

[14] Tavares, S., Castro, P.R.C., Ribeiro, R.V. and Aramaki, P.H. (2008) Avaliação dos efeitos fisiológicos de tiametoxam no tratamento de sementes de soja. In: Gazzoni, D.L., Ed., Tiametoxam: Uma revolução na agricultura brasileira, Bogotá, Colômbia, 193-204.

[15] Tavares, S., Castro, P.R.C., Ribeiro, R.V. and Aramaki, P.H. (2007) Avaliação dos efeitos fisiológicos de tiametoxam no tratamento de sementes de soja. Revista de Agricultura (Piracicaba), 82, 47-54.

[16] Almeida, A.S., Carvalho, I., Deuner, C., Villela, F.A. and Tillmann, M.A.A. (2011) Bioativador no desempenho fisiológico de sementes de arroz (Oryza sativa L.). Revista Brasileira de Sementes, 33, 501-510.

http://dx.doi.org/10.1590/S0101-31222011000300013 
Scientific Research Publishing (SCIRP) is one of the largest Open Access journal publishers. It is currently publishing more than 200 open access, online, peer-reviewed journals covering a wide range of academic disciplines. SCIRP serves the worldwide academic communities and contributes to the progress and application of science with its publication.

Other selected journals from SCIRP are listed as below. Submit your manuscript to us via either submit@scirp.org or Online Submission Portal.
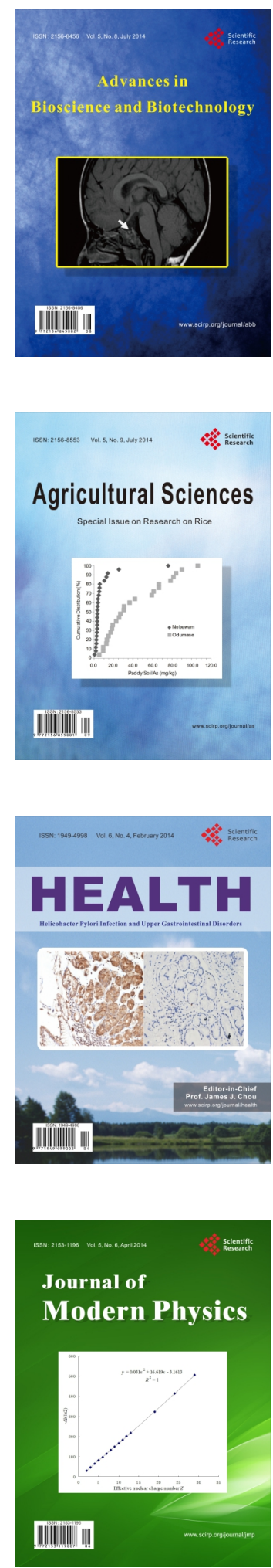
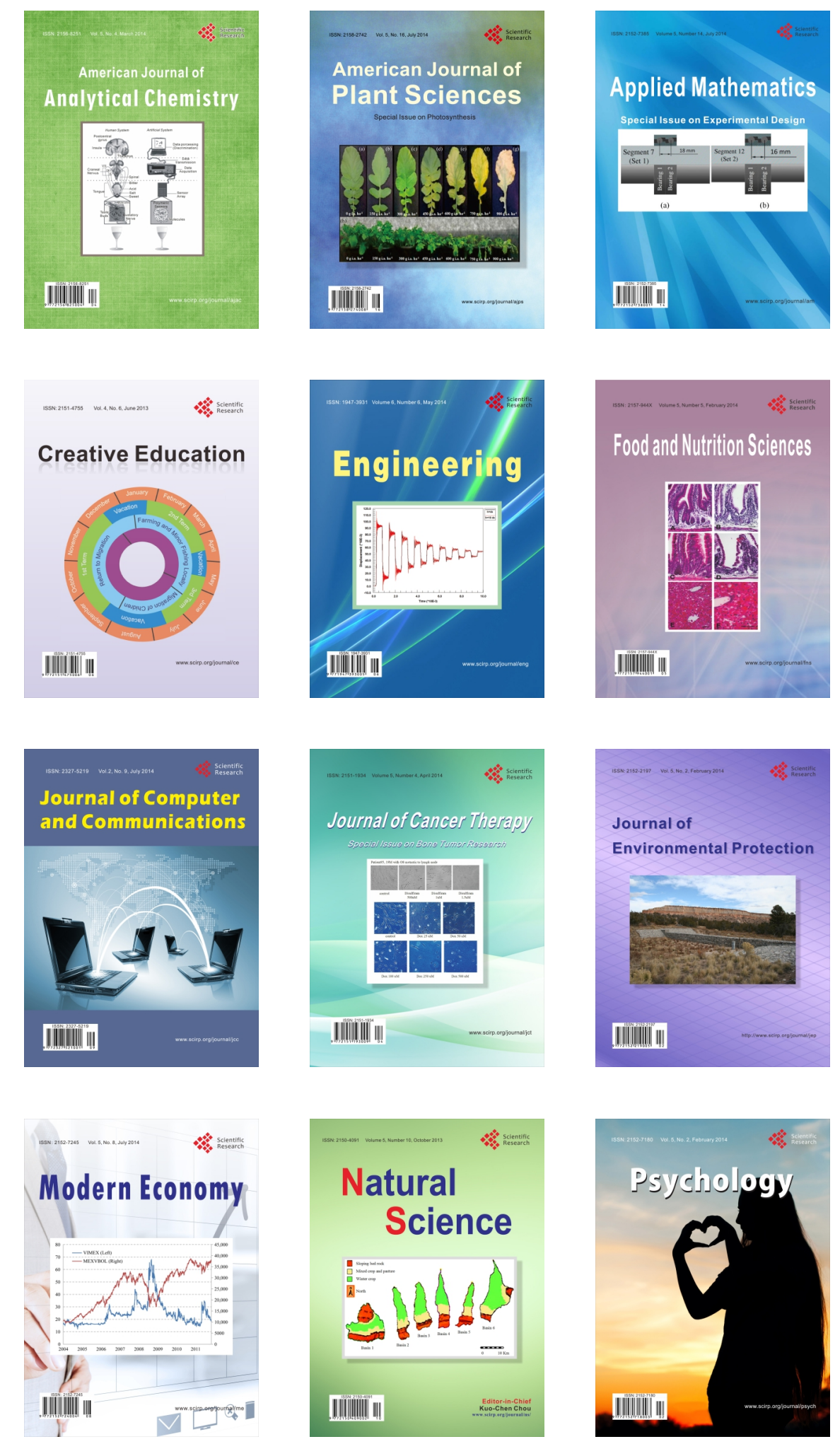